\title{
Sedimentation Survey of Lago Patillas, Puerto Rico, April 1997
}

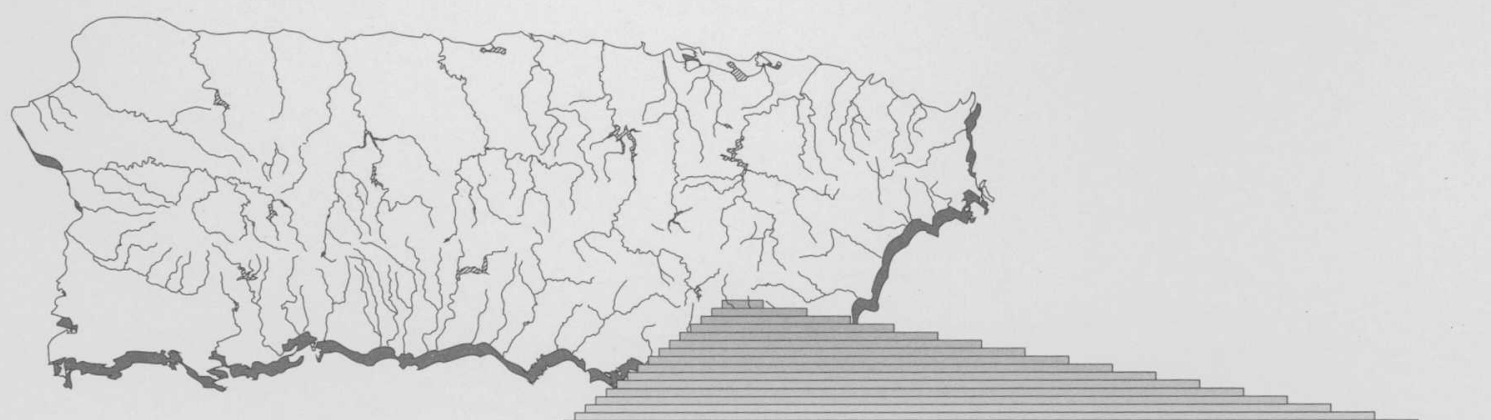

Water-Resources Investigations Report 99-4030

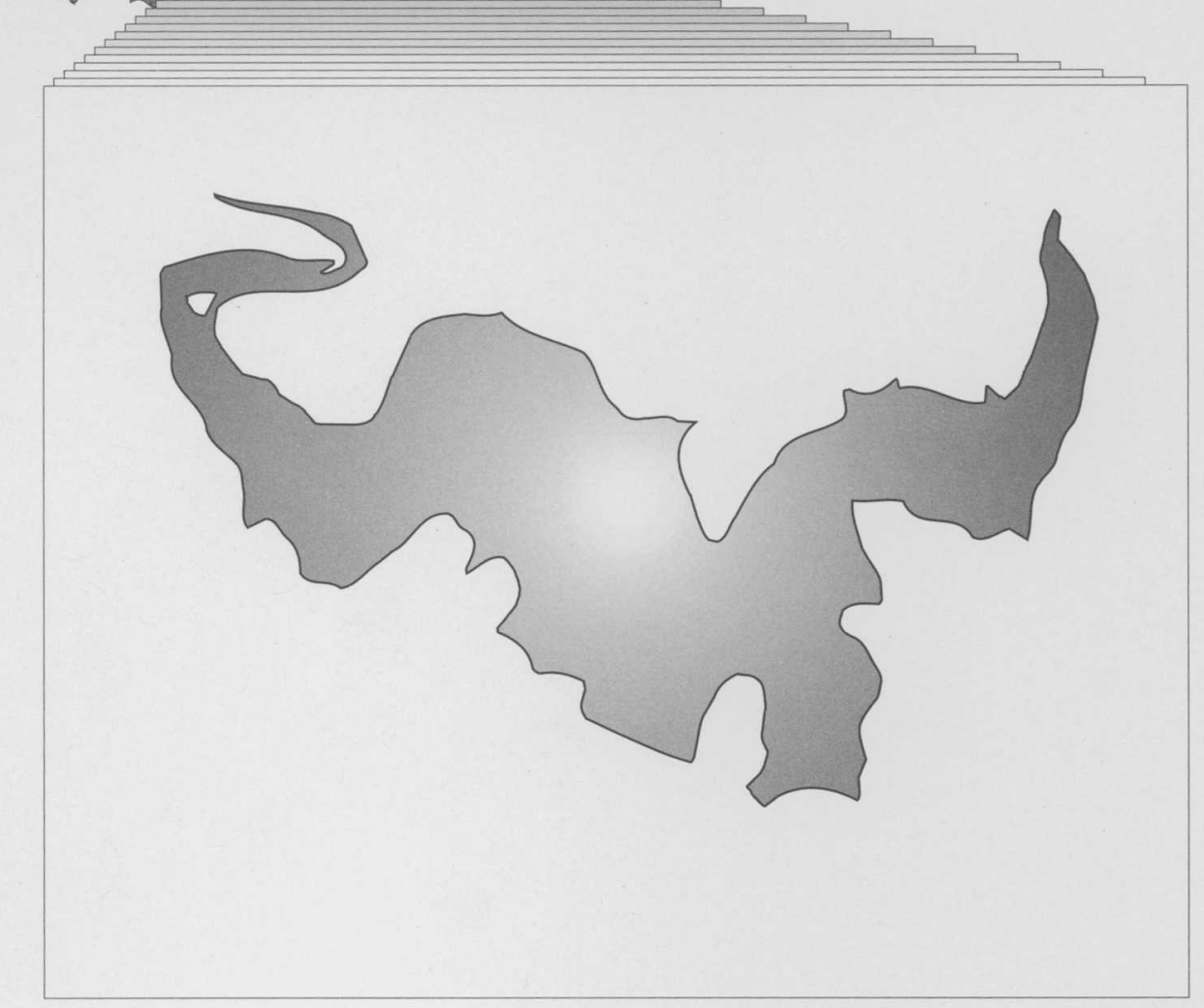




\section{Sedimentation Survey of Lago Patillas, Puerto Rico, April 1997}

By Luis R. Soler-López, Richard M.T. Webb, and Francisco Pérez-Blair

Water-Resources Investigations Report 99-4030

In cooperation with the

PUERTO RICO ELECTRIC POWER AUTHORITY

San Juan, Puerto Rico: 1999 


\section{U.S. DEPARTMENT OF THE INTERIOR \\ BRUCE BABBITT, Secretary}

\section{U.S. GEOLOGICAL SURVEY}

Charles G. Groat, Director

Use of trade names in this report is for identification purposes only and does not imply endorsement by the U.S. Government.

For additional information write to:

District Chief

U.S. Geological Survey GSA Center, Suite 400-15

651 Federal Drive

Guaynabo, Puerto Rico 00965-5703
Copies of this report can be purchased from:

U.S. Geological Survey

Branch of Information Services

Box 25286

Denver, C0 80225-0286 


\section{CONTENTS}

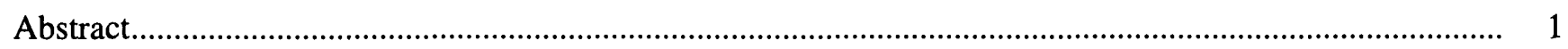

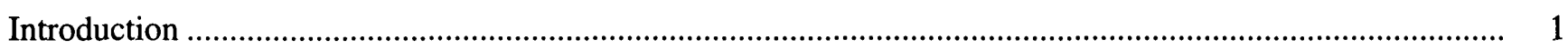

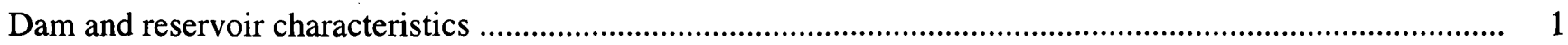

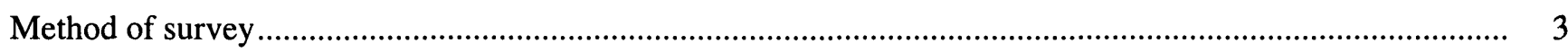

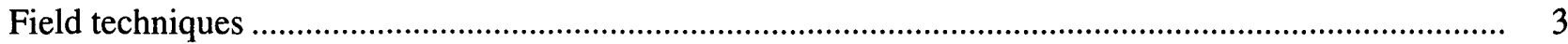

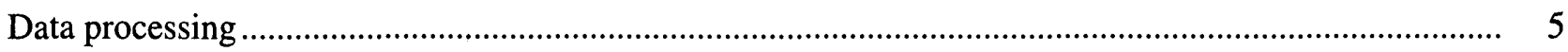

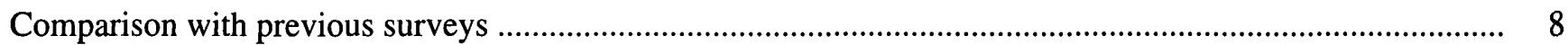

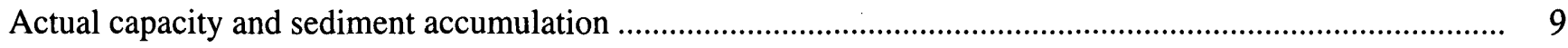

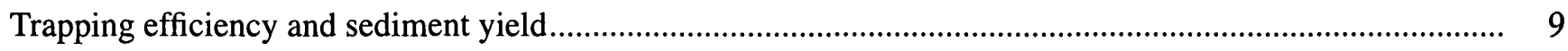

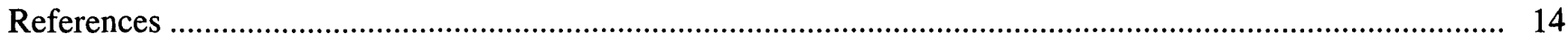

\section{PLATE}

[Plate is in pocket]

1. Lago Patillas, Puerto Rico, Bathymetry, April 1997 


\section{FIGURES}

1.-4. Map showing:

1. Location of Lago Patillas in the southeastern part of Puerto Rico.

2. Planned cross-section locations for the 1997 bathymetric survey of Lago Patillas, Puerto Rico

3. Track lines where data were collected during the 1997 bathymetric survey of Lago Patillas, Puerto Rico

4. Reference distances for longitudinal profiles of Lago Patillas, Puerto Rico, during the April 1997 bathymetric survey

5.-7. Graph showing

5. Selected cross sections generated from TIN surface model of Lago Patillas, Puerto Rico, for 1997

6. Longitudinal profiles for 1997 along the Spillway, Río Marín, and the Río Grande de Patillas branches of Lago Patillas, Puerto Rico

7. The relation between pool elevation and volume derived from triangulated irregular network surface model and from photogrammetric methods for Lago Patillas, Puerto Rico

\section{TABLES}

1. Principal characteristics of Lago Patillas and Patillas dam, Puerto Rico

2. Summary data for sedimentation surveys of Lago Patillas, Puerto Rico. 


\begin{tabular}{rcl}
\hline Multiply & By & To obtain \\
millimeter & Length & \\
centimeter & 0.03937 & inch \\
meter & 0.032808 & foot \\
kilometer & 3.2808 & foot \\
& 0.62137 & mile \\
square meter & Area & \\
square kilometer & 10.7639 & square foot \\
square kilometer & 0.3861 & square mile \\
& 247.11 & acre \\
cubic meter & Volume & \\
cubic meter & 35.315 & cubic foot \\
million cubic meters & 0.0008107 & acre-foot \\
& 810.7 & acre-foot \\
cubic meter per second & 35.315 & cubic foot per second \\
cubic meter per second & 15,850 & gallon per minute \\
cubic meter per second & 22.826 & million gallons per day \\
\hline
\end{tabular}

Horizontal Datum - Puerto Rico Datum, 1940 Adjustment

Sea level: In this report, "sea level" refers to the National Geodetic Vertical Datum of 1929 (NGVD of 1929)-a geodetic datum derived from a general adjustment of the first-order level nets of both the United States and Canada, formerly called "Sea Level Datum of 1929."

\section{Acronyms used in this report:}

$\begin{array}{ll}\text { BLASS } & \text { Bathymetric/Land Survey System } \\ \text { DGPS } & \text { Differential Global Positioning System } \\ \text { GIS } & \text { Geographic Information System } \\ \text { PREPA } & \text { Puerto Rico Electric Power Authority } \\ \text { TIN } & \text { Triangulated Irregular Network } \\ \text { USGS } & \text { U.S. Geological Survey }\end{array}$




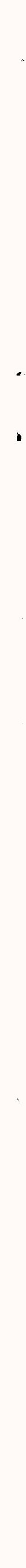




\title{
Sedimentation Survey of Lago Patillas, Puerto Rico, April 1997
}

\author{
By Luis R. Soler-López, Richard M.T. Webb, and Francisco Pérez-Blair
}

\begin{abstract}
Sedimentation has reduced the storage capacity of Lago Patillas by approximately 22 percent since 1961 . The storage capacity has decreased from 17.64 million cubic meters in 1961 to 13.84 million cubic meters in 1997 . The long-term sedimentation rate is calculated to be about 0.11 million cubic meters per year which represents an annual loss of capacity of 0.62 percent: The rate of capacity loss has increased from 0.05 million cubic meters per year from 1961 to 1977 to 0.15 million cubic meters per year from 1977 to 1997 . The trap efficiency of Lago Patillas is estimated to be about 93 percent and the average sediment yield of the basin is about 1,740 cubic meters per square kilometer per year.
\end{abstract}

\section{INTRODUCTION}

The U.S. Geological Survey (USGS) in cooperation with the Puerto Rico Electric Power Authority (PREPA) is conducting sedimentation surveys in most of the reservoirs owned by the PREPA. During April 8-10, 1997, the USGS conducted a survey to determine the current storage capacity of Lago Patillas, determine rates of storagecapacity loss, and prepare a detailed bathymetric map of the reservoir bottom. These data will be useful in evaluating the feasibility of dredging the lake to increase its storage capacity. Data on geographic position and water depths were simultaneously acquired with a differential global positioning system
(DGPS) and a depth sounder and then stored directly in digital form. The digitized data were transferred into a geographic information system (GIS) for processing and analysis. The GIS was then used to calculate the storage capacity as of April 1997.

\section{DAM AND RESERVOIR CHARACTERISTICS}

Lago Patillas reservoir was completed in 1914. The Patillas dam is located immediately downstream of the original confluence of the Río Grande de Patillas and the Río Marín, about 1.6 kilometers northwest of the town of Patillas (fig. 1). The Lago Patillas reservoir was built to provide water for the irrigation of croplands in the towns of Guayama, Patillas, and Salinas along the south coast of Puerto Rico. Irrigation releases are made through the outlet works into the Patillas Irrigation Canal (Canal de Patillas) that extends 32.2 kilometers from the Patillas dam to the Río Salinas.

The Patillas dam is a semi-hydraulic earthfill with a structural height of 44.81 meters, a top width of 4.51 meters, a base width of 190.50 meters, and a crest length of 325.22 meters. The spillway, which is physically separated from the dam, has a crest elevation of 58.22 meters above mean sea level. The spillway consists of an approach channel, a concrete gate structure with three radial arm gates that are 9.14 meters wide by 10.17 meters high, and an open chute. The maximum discharge capacity at a pool elevation of 70.10 meters above mean sea level is 2,237 cubic meters per second (PREPA, 1979). The principal characteristics of Lago Patillas and structures are listed in table 1 . 


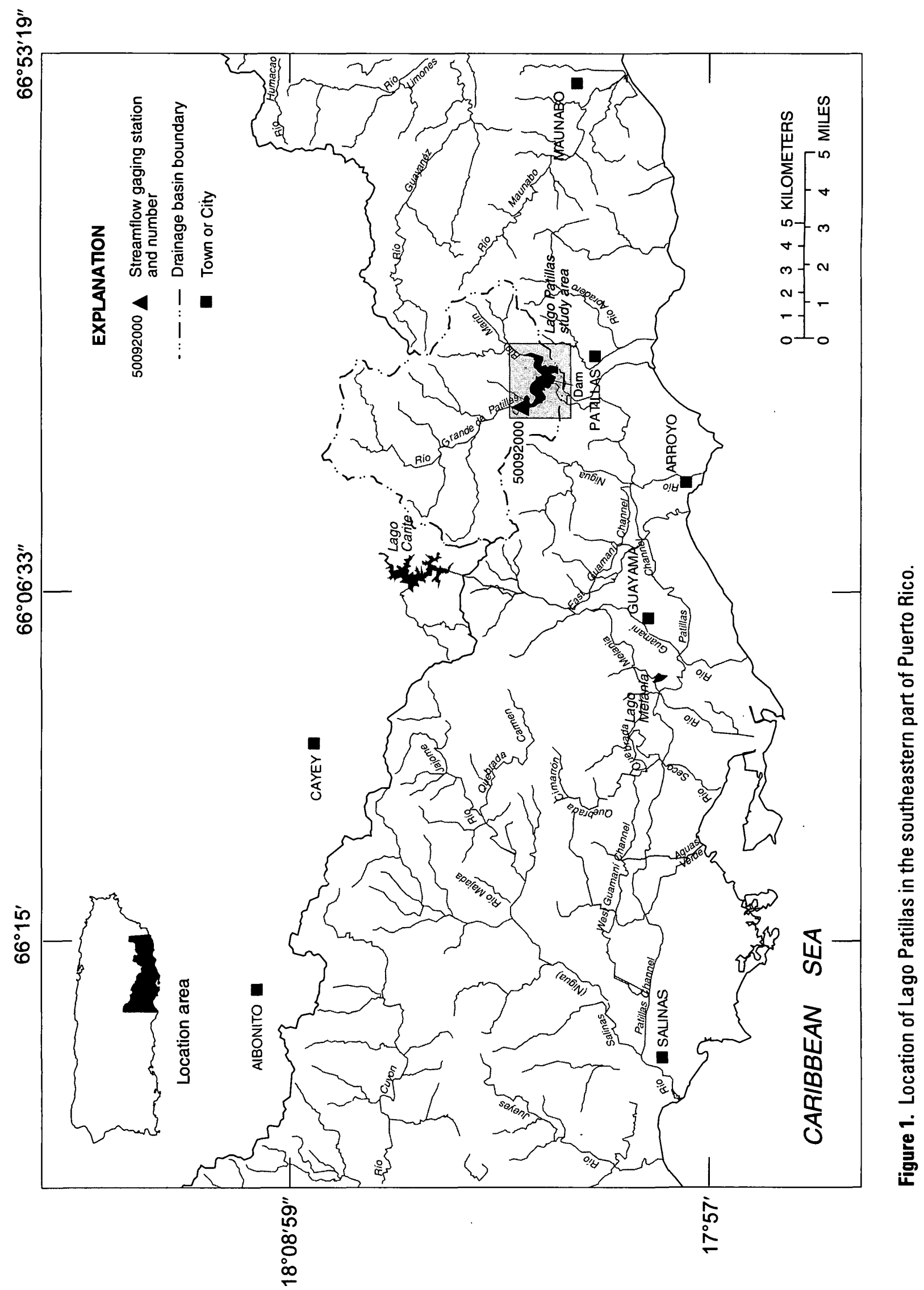


Table 1. Principal characteristics of the Lago Patillas and Patillas dam, Puerto Rico (Modified from Puerto Rico Electric Power Authority, 1979)

[Elevations in meters above mean sea level]

Length of Dam 325.22 meters

Elevation of top of dam. 72.54 meters

Maximum pool elevation. .70 .10 meters

Normal pool elevation 67.67 meters

Elevation of crest of spillway 58.22 meters

Maximum spillway discharge (pool elevation of 70.10 meters). 2,237 cubic meters per second

Storage capacity at normal pool elevation ${ }^{1}$ 13.84 million cubic meters

Surcharge storage for flood control 3.41 million cubic meters

Drainage area at dam site 65.27 square kilometers

Flooded area at top of dam elevation 1.62 square kilometers

Flooded area at maximum pool elevation 1.49 square kilometers

Maximum length of normal pool

Río Grande de Patillas branch. 2.89 kilometers

Río Marín branch 1.95 kilometers

Maximum depth during 1997 survey $^{2}$ 24.0 meters

11997 capacity at pool elevation of 67.67 meters.

2 Below normal pool elevation of 67.67 meters.

\section{METHOD OF SURVEY}

The 1997 sedimentation survey of Lago Patillas was conducted in four phases: selection of crosssection locations, acquisition of data, processing of data, and analysis of data. A geographic information system, Arc/Info, was used to plan the survey lines and to analyze the bathymetric data. Cross-section locations were established at spacing of 50 meters along the Río Grande de Patillas, Río Marín, and spillway branches (fig. 2). Water depth and geographic position were acquired simultaneously using a differential global positioning system interfaced to a depth sounder. The soundings were subsequently adjusted to represent depths below the normal pool elevation. Depths below normal pool elevation can be converted to elevations above mean sea level by substracting the depth value from the normal pool elevation of 67.67 meters above mean sea level. The pool elevation during the sedimentation survey (April $8-10,1997)$ decreased from 67.18 to 67.13 meters. Although this change in the pool elevation can be considered negligible, a time-elevation correction factor was applied to adjust the measured depths to represent depth below normal pool elevation. A bathymetric map of the reservoir bottom for April 1997 was then constructed.

\section{Field Techniques}

The sedimentation survey of Lago Patillas was conducted April 8-10, 1997. Data were collected with the bathymetric/land survey systems (BLASS), developed by Specialty Devices, Inc. The system uses two Motorola SixGun DGPS receivers. The DGPS units were first used in a static survey mode to establish a reference mark at a site near the reservoir. 


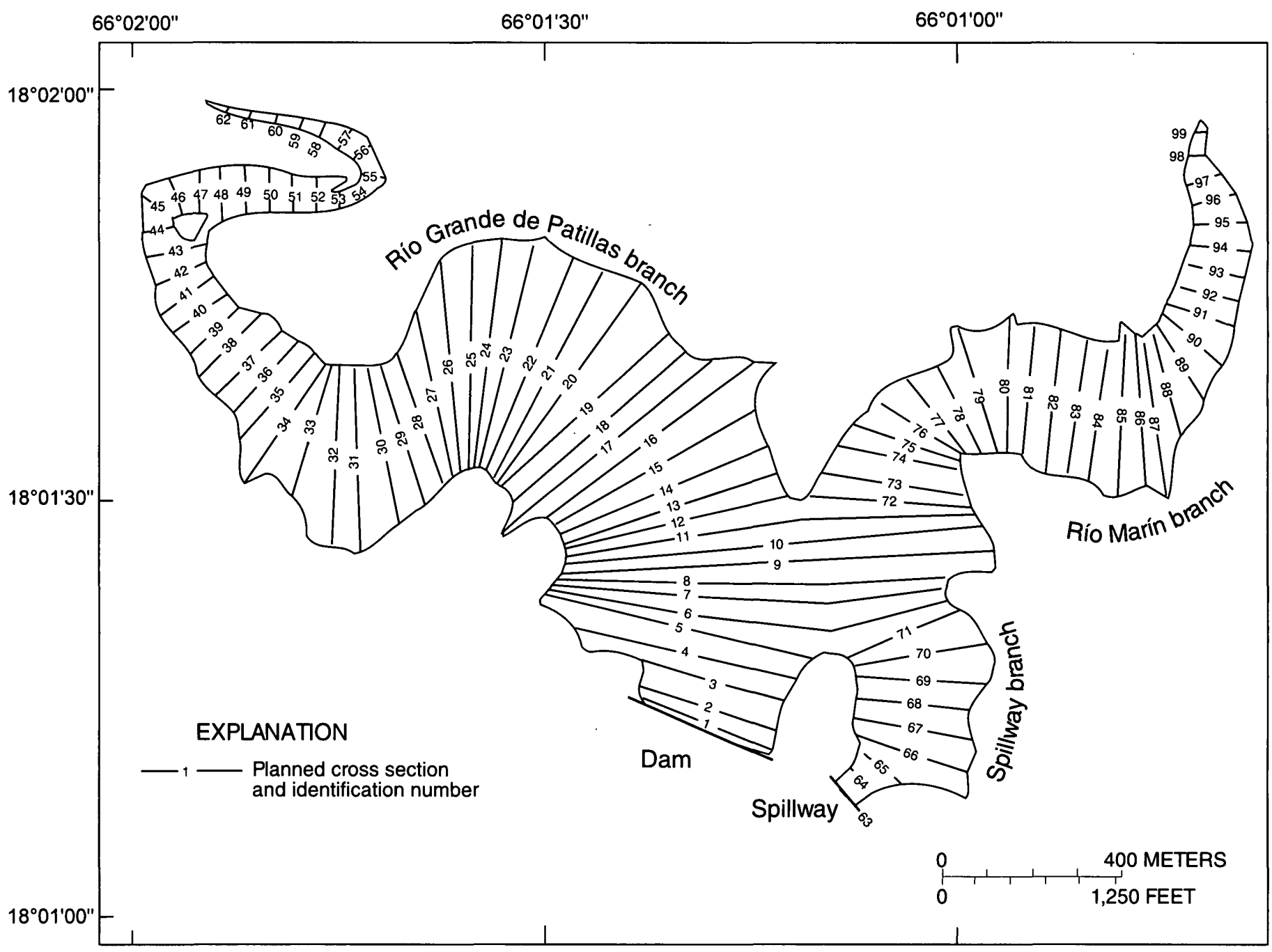

Figure 2. Planned cross-section locations for the 1997 bathymetric survey of Lago Patillas, Puerto Rico. 
Satellite information was simultaneously recorded for a 45-minute session at a control station POLLO (USGS lat $17^{\circ} 58^{\prime} 48.070^{\prime \prime} \mathrm{N}$., long $66^{\circ} 00^{\prime} 10.400^{\prime \prime} \mathrm{W}$.) and at a reference station PAT-2 (lat $18^{\circ} 01^{\prime} 10.275^{\prime \prime} \mathrm{N}$., long $66^{\circ} 01^{\prime} 22.999^{\prime \prime} \mathrm{W}$.) located at a point overlooking the reservoir. Post-processing, using the software CentiPoint (GPSsoft, Inc.), showed a horizontal error of less than 10 centimeters for point PAT-2.

Once PAT 2 was established, one DGPS was installed there as the master station and the other DGPS was installed in the survey boat as the mobile station. The DGPS on board the survey boat independently calculated a position every second while receiving a set of pseudo-range corrections transmitted from the reference station every 5 seconds, to maintain a positional accuracy within 2 meters. Water depths were measured using a RAYTHEON DE-719B depth recorder coupled to an ODOM DIGITRACE to record data both in digital and analog form. The depth recorder reports depths to the nearest 0.1 meter and was calibrated in water depths of 3 and 22 meters. The bathymetric survey software HYPACK (Coastal Oceanographics, Inc.) received and recorded the geographic positions and the depths once every second while in survey mode. HYPACK runs on a portable personal computer and is used to record data and to navigate. The helmsman of the survey boat is provided with a graphical display showing the lakeshore, the location of the planned cross sections, the actual position of the boat while underway, and indicators of speed and the amount of deviation from the planned track lines.

A total of 99 cross sections at a 50-meter spacing were planned; however, sediment accumulation in the upper reach of the Río Grande de Patillas and the Río Marín branches limited the bathymetric data collection to only 74 cross sections. Bathymetric data were collected from the dam to cross section 91 along the Río Marín branch, from the dam to cross section 47 along the Río Grande de Patillas branch and from the spillway to cross section 71 along the Spillway branch (fig. 3). Reference distances along the Río Grande de Patillas, Río Marín, and Spillway branches are shown in figure 4. At the beginning and end of each day of surveying, the survey boat was secured to an assigned point on the shore and positional data were recorded for at least 30 seconds to verify the precision of the DGPS-calculated positions.

Random errors can appear in positional data because of GPS calculation errors or topographic interference by elevated land surfaces. When the latter occurred, a signal repeater was installed to "bounce" the signal into the mobile DGPS unit. Also, errors in depth data can occur because of bubbles obstructing the transducer face or because of insufficient signal gain. Physical or electronic problems encountered in the field were corrected as soon as they were detected. If the section of missing or bad data extended more than 20 meters, that cross section was rerun. If the amount of erroneous data occurred for less than 20 meters along the cross section, and the reservoir bottom exhibited no change in slope before and after the data were lost, the section was not rerun but the data file was flagged for later editing.

\section{Data Processing}

Initial editing and verification of the positional and depth data were performed within the HYPACK program. Positions were corrected to eliminate anomalous spikes. Spikes or jumps in the positional data may occur when reception of the satellite's signal is obstructed by local topographic features or disrupted by electromagnetic interference. In such instances, the location of the sounding may be erroneously calculated to be several hundred meters from the actual position one second before or one second after that data point was acquired. In these cases the erroneous positions were interpolated back to the midpoints between the antecedent and posterior positions. Loss of positional data as a result of elevated land surfaces between the mobile station and the reference station occurred on the Río Grande de Patillas branch. To account for this positional data loss, a signal repeater was installed on a hill overlooking the Río Grande de Patillas branch to cover that area. Depth contours were drawn at variable intervals.

Quality checks of the positional data collected during the bathymetric survey indicate that 90 percent of the calculated positions were within 2 meters of their true geographic positions. This indicates that 90 percent of the points on a 1:20,000 scale map are within 10 meters of their plotted position on the map. 


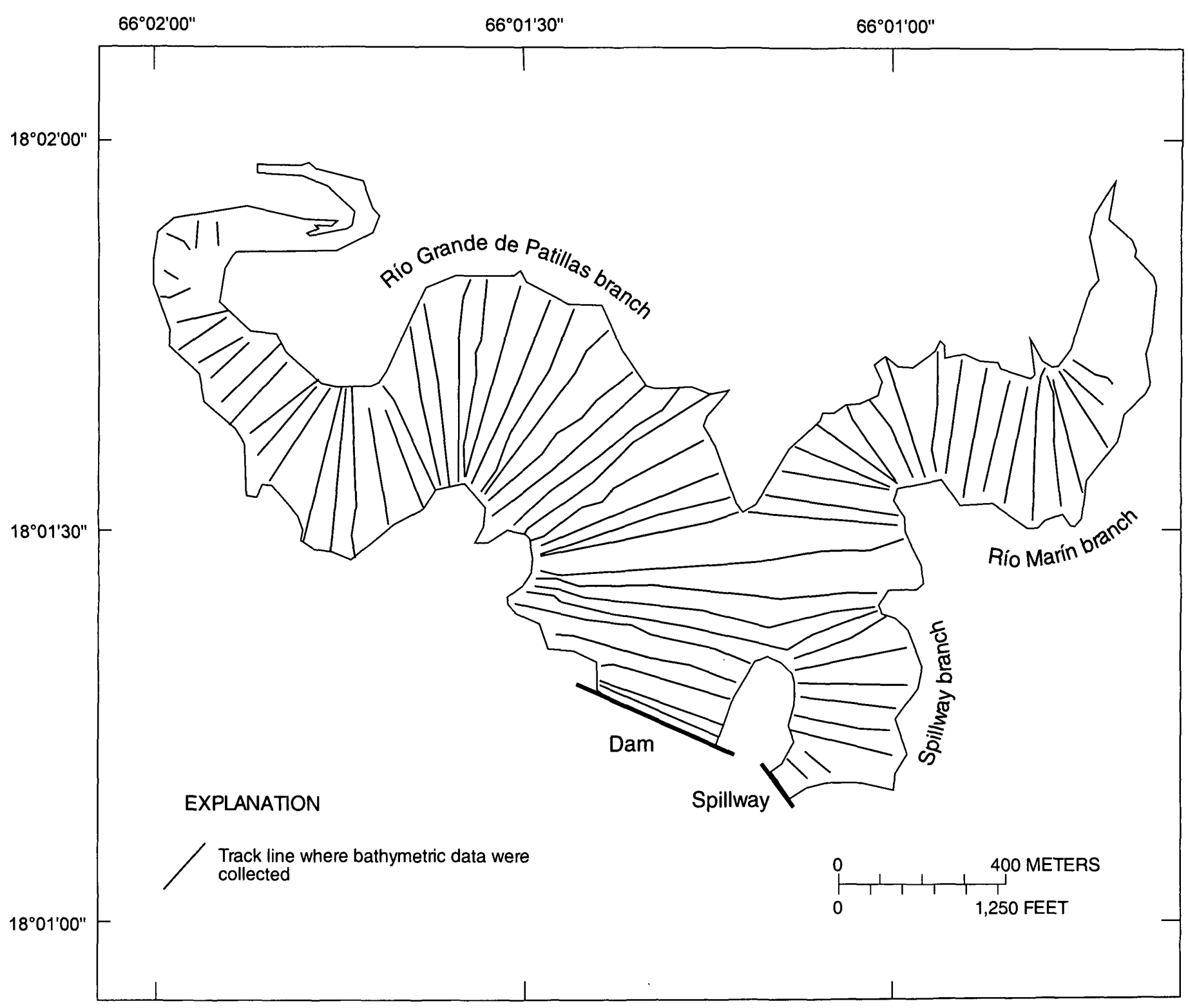

Figure 3. Track lines where data were collected during the 1997 bathymetric survey of Lago Patillas, Puerto Rico. 


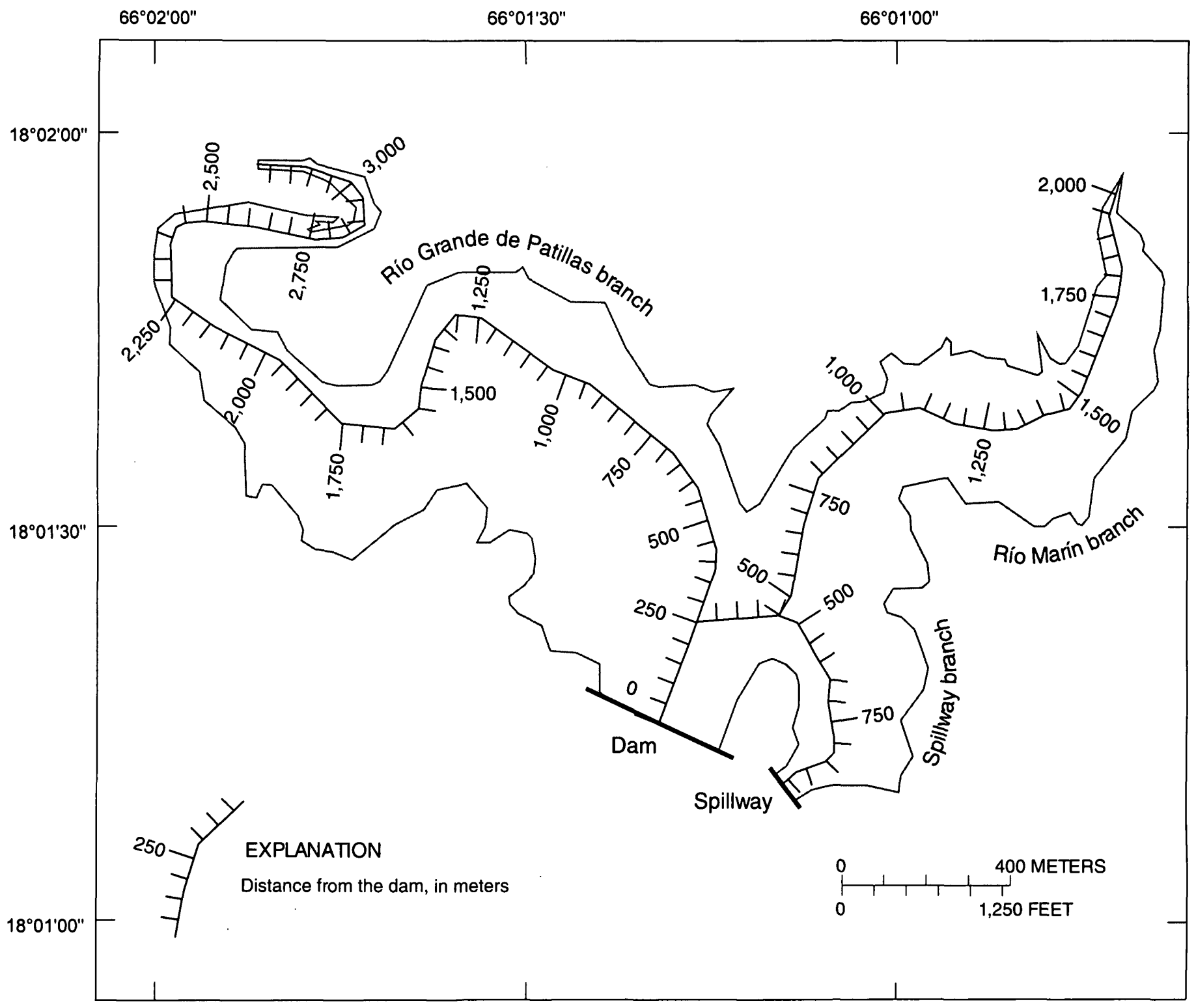

Figure 4. Reference distances for longitudinal profiles of Lago Patillas, Puerto Rico, during the April 1997 bathymetric survey. 
The bathymetric contour lines were then converted into a surface model by creating a triangulated irregular network. The TIN surface model of the reservoir bottom consists of thousands of adjoining triangles with $\mathrm{x}, \mathrm{y}$, and $\mathrm{z}$ coordinates assigned to all vertices (Environmental Systems Research Institute, Inc., 1992). The volume of the reservoir was then calculated at incremental pool elevations of 1 meter to develop a stage-storage curve.

\section{COMPARISON WITH PREVIOUS SURVEYS}

The storage capacity at normal pool elevation of the Lago Patillas reservoir in 1961 was calculated to be 17.64 million cubic meters (U.S. Bureau of Reclamation, 1976). In 1977, the USGS conducted a bathymetric study of Lago Patillas. The storage capacity at normal pool elevation for this study was
16.90 million cubic meters (USGS, unpublished data, 1977). The actual storage capacity, calculated from the 1997 sedimentation survey was 13.84 million cubic meters. The 1961 storage capacity was calculated from a topographic map of the reservoir area produced in March 1961 after the reservoir was emptied to construct a new outlet works. The 1977 survey calculated the volume using a precision survey echo sounder to measure water depths. Velocity meters were used to determine distances from the banks and to mark the section record. This survey used the modified prismoidal formula to calculate incremental estimates of volume for the reservoir based on the area of the reservoir at three elevations (Heinemann and Dvorak, 1963). The 1997 volume was calculated using a TIN. Data for prior and current sedimentation surveys of Lago Patillas are summarized in table 2.

Table 2. Summary data for sedimentation surveys of Lago Patillas, Puerto Rico

[Elevation datum, National Geodetic Vertical Datum 1929, ---, not applicable]

\begin{tabular}{lccc}
\hline & 1961 & 1977 & 1997 \\
\hline $\begin{array}{l}\text { Capacity at normal pool elevation of 67.67 meters (million cubic } \\
\text { meters) }\end{array}$ & 17.64 & 16.90 & 13.84 \\
$\begin{array}{l}\text { Years since construction } \\
\text { Years since previous survey }\end{array}$ & 47 & 63 & 83 \\
Sediment accumulated since 1961 (million cubic meters) & --- & 16 & 20 \\
$\begin{array}{l}\text { Storage loss since 1961 (percent) } \\
\text { Annual loss of capacity since 1961 (million cubic meters) }\end{array}$ & --- & 0.74 & 3.80 \\
$\begin{array}{l}\text { Annual loss of capacity since 1961 (percent) } \\
\text { Rate of capacity loss since previous survey (million cubic meters } \\
\text { per year) }\end{array}$ & ---- & 4 & 22 \\
Approximate year that reservoir would fill with sediment ${ }^{2}$ & -- & 0.05 & 0.62 \\
\hline
\end{tabular}

1 No data are available for sedimentation surveys prior to 1961.

${ }^{2}$ Assuming that the reservoir would continue to fill at the long-term sedimentation rate; in reality the reservoir sedimentation rate decreases with time since the trapping efficiency of the reservoir decreases as the reservoir fills with sediment. 


\section{ACTUAL CAPACITY AND SEDIMENT ACCUMULATION}

The storage capacity at a normal pool elevation of 67.67 meters above mean sea level was $\mathbf{1 7 . 6 4}$ million cubic meters in 1961, decreasing to 16.90 million cubic meters in 1977 and to 13.84 million cubic meters in 1997 . This represents a capacity reduction of 3.80 million cubic meters in 36 years or a capacity loss of 0.62 percent per year. Most of this sedimentation, 3.06 million cubic meters, has occurred in the last twenty years. A large amount of this deposited material, from 1977 to 1997, was probably transported by the four largest recorded floods since 1966. These floods in decreasing order of magnitude are the flood of January 5, 1992 (peak flow 875 cubic meters per second), the flood of September 10, 1996 (Hurricane Hortense, peak flow 635 cubic meters per second), the flood of July 11, 1993 (peak flow 495 cubic meters per second) and the flood of August 31, 1979 (peak flow 415 cubic meters per second).

The bathymetric map of the April 1997 survey (Plate 1) shows depth contours of the reservoir bottom. The maximum depth is 24 meters and the contour interval is variable. Locations of selected cross sections of the reservoir are shown on figure 2 . The sediment accumulation is evident on the Río Grande de Patillas branch as the surveyed cross sections appear flat on the bottom (fig. 5, cross sections 5 to 42 ) indicating that the original river channel has been filled with sediment. On the Río Marín branch the sediment accumulation is also evident (fig. 5, cross sections 67 to 85). Longitudinal profiles of the Río Grande de Patillas, Río Marín, and the Spillway branches are shown in figure 6 .

Stage-storage curves were produced for the 1961 and 1997 studies (fig. 7). The 1961 curve provided by PREPA was developed by photogrammetric methods, and the 1997 curve was derived from the 1997 TIN. The storage-storage relation for the 1997 survey was calculated at reservoir depth increments of 1 meter from the minimum to the maximum depth of the 1997 survey.

\section{TRAPPING EFFICIENCY AND SEDIMENT YIELD}

The trapping efficiency of the reservoir was estimated by using the capacity/inflow ratio described by Brune (1953). The Lago Patillas has two tributaries, Río Grande de Patillas and Río Marín. The inflow to the reservoir from the Río Grande de Patillas was calculated from the streamflow data recorded during 31 years at the Río Grande de Patillas near Patillas gaging station (station number 50092000). The mean annual runoff was calculated as 50.24 million cubic meters (Díaz and others, 1997).

Since there is no stream gaging station on the Río Marín to measure the inflow to the reservoir, the average annual runoff was estimated by using a mean annual rainfall of 2,032 millimeters (Calvesbert, 1970) and the same rainfall/runoff ratio of the Rio Grande de Patillas basin (0.5) (Giusti and López, 1967). Thus, the mean annual runoff was calculated to be 1,016 millimeters or equivalent to 1.02 million cubic meters per square kilometer. Based on a drainage area of 11.52 square kilometers for the Río Marín above Lago Patillas, the mean annual runoff entering the reservoir from the Río Marín was calculated to be 11.75 million cubic meters. Thus, the total inflow entering Lago Patillas was calculated to be 61.99 million cubic meters per year.

On the basis of the 1997 storage capacity of 13.84 million cubic meters and a mean annual runoff of 61.99 million cubic meters, the capacity/inflow ratio of Lago Patillas is 0.22 . The trap efficiency using relations established by Brune (1953) is about 93 percent.

The sediment yield has been defined by the American Society of Civil Engineers as the total sediment outflow from a catchment or drainage basin, measurable at a point of reference and a specified period of time (McManus and Duck, 1993). The sediment yield of the basin for 36 years, 4.09 million cubic meters, was estimated by dividing the amount of sediment deposited since 1961 by the trapping efficiency of the reservoir (3.80/0.93). Based on the 65.27 square kilometers drainage area of the reservoir and 36 years of accumulation, the sediment yield of the basin was computed to be 1,740 cubic meters per square kilometer per year. 


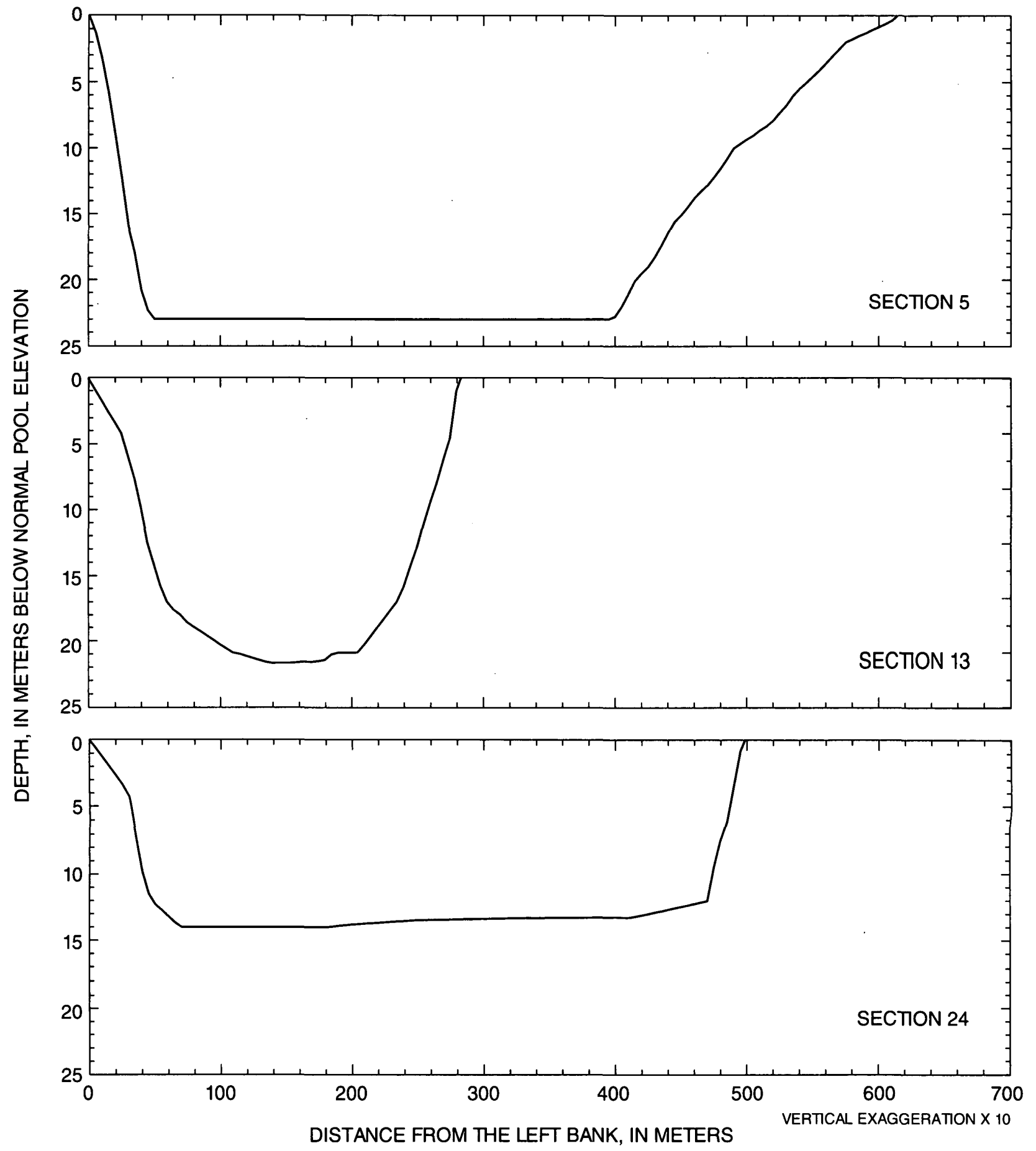

Figure 5. Selected cross sections generated from TIN surface model of Lago Patillas, Puerto Rico, for 1997 (refer to fig. 2 for their locations). 


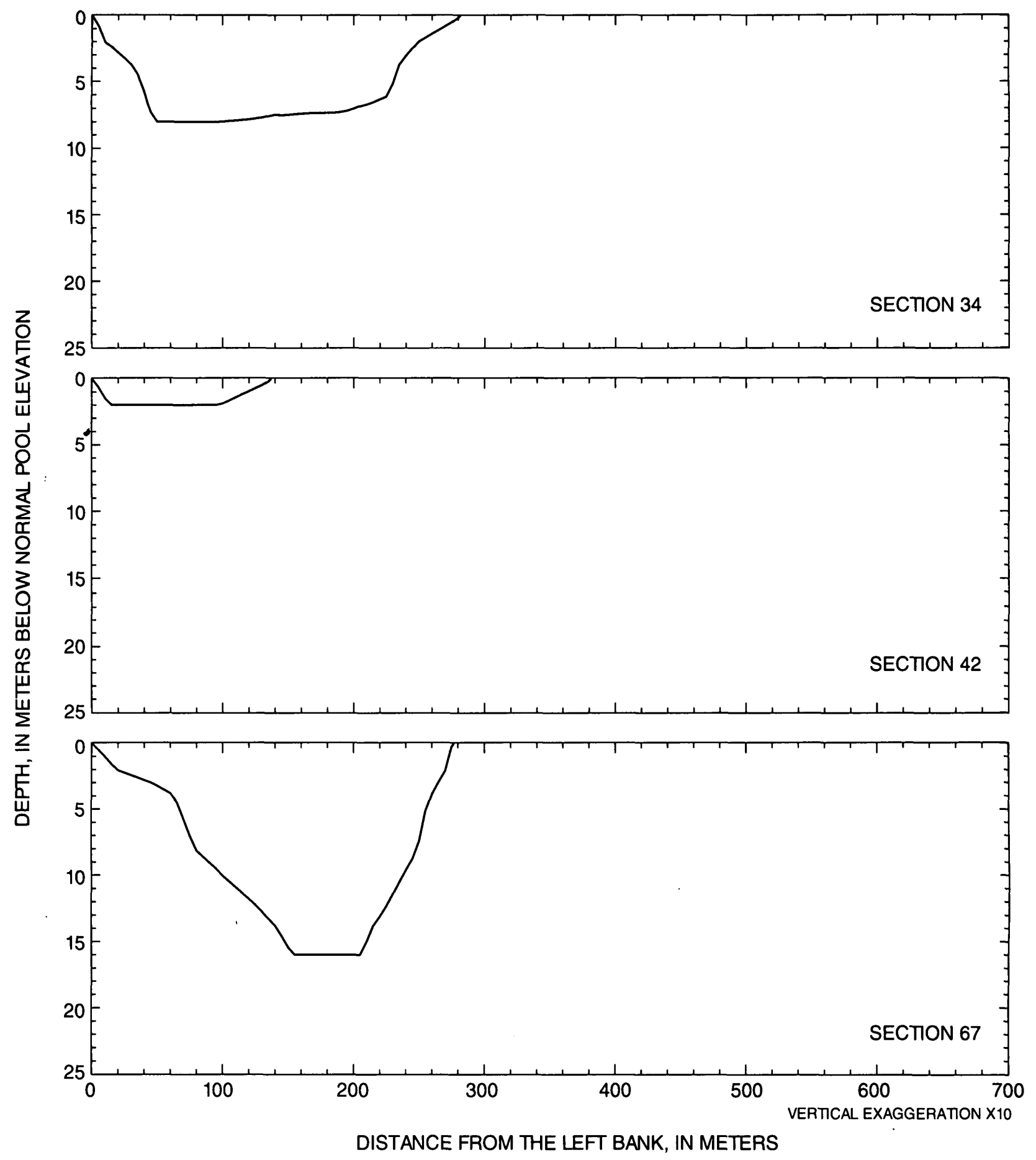

Figure 5. Selected cross sections generated from TIN surface model of Lago Patillas, Puerto Rico, for 1997 (refer to fig. 2 for their locations)-Continued. 


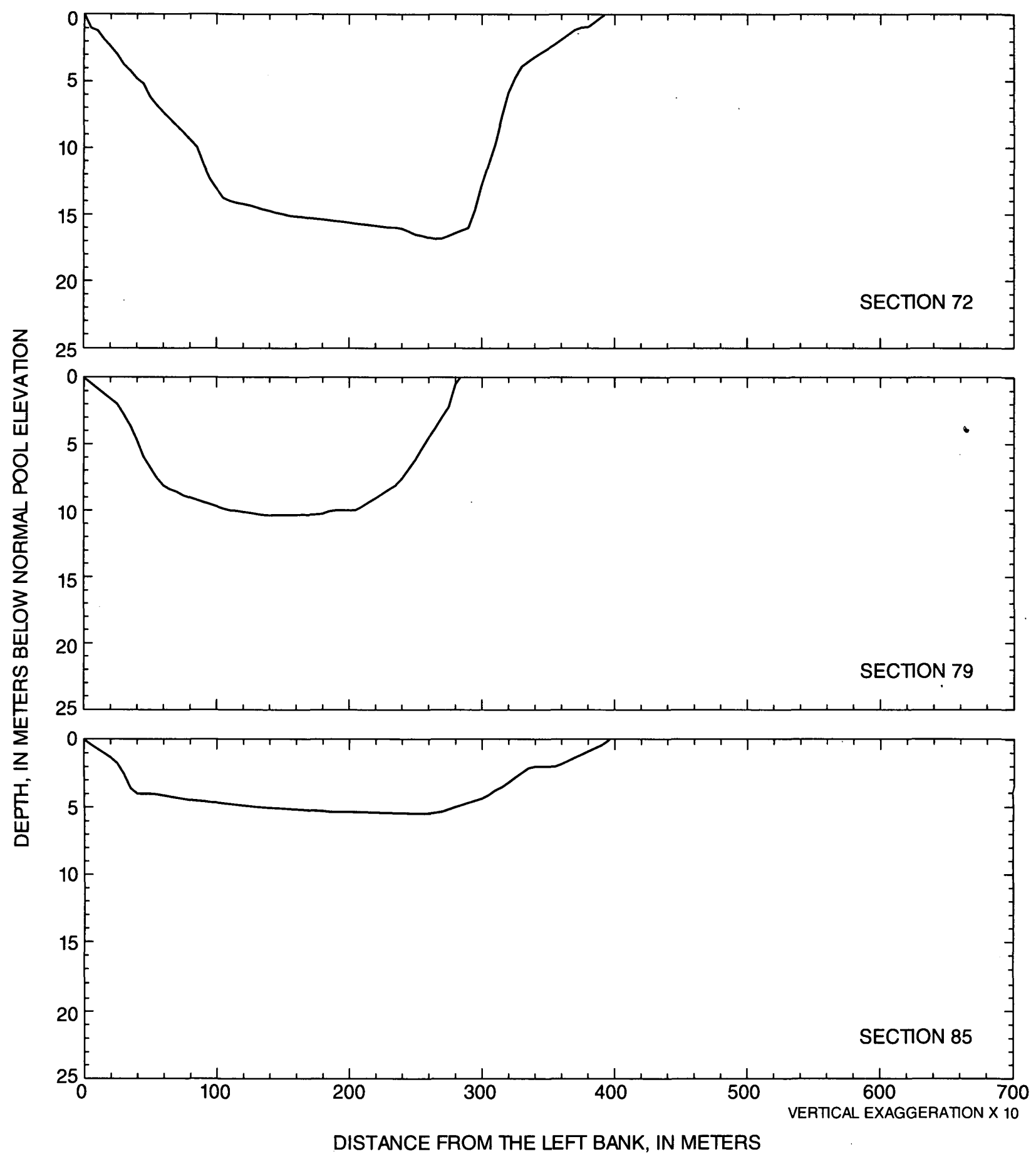

Figure 5. Selected cross sections generated from TIN surface model of Lago Patillas, Puerto Rico, for 1997 (refer to fig. 2 for their locations)-Continued. 

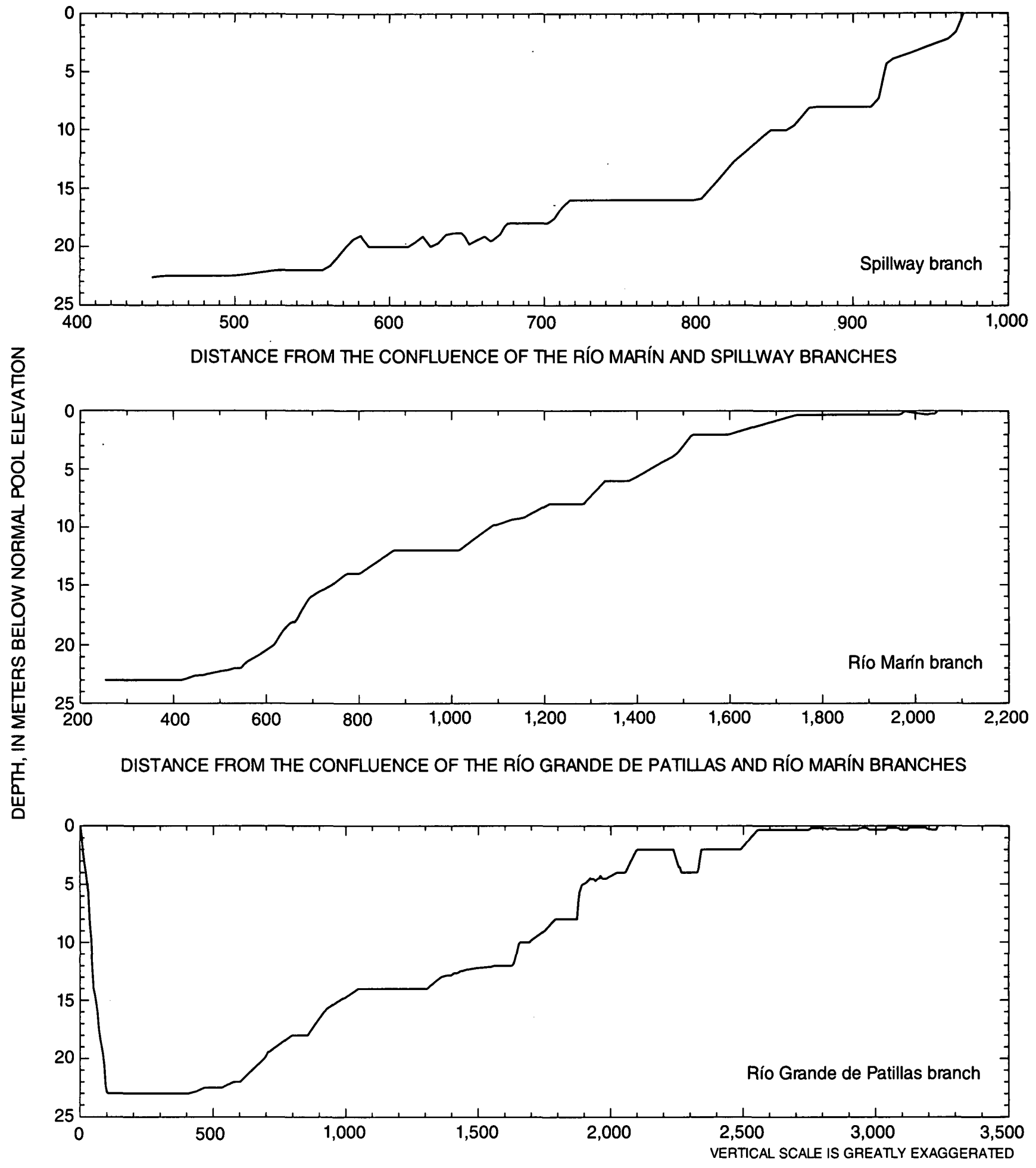

DISTANCE FROM THE DAM, IN METERS, ALONG THE RÍO GRANDE DE PATILAS BRANCH

Figure 6. Longitudinal profiles for 1997 along the Spillway, Río Marín, and the Río Grande de Patillas branches of Lago Patillas, Puerto Rico. 


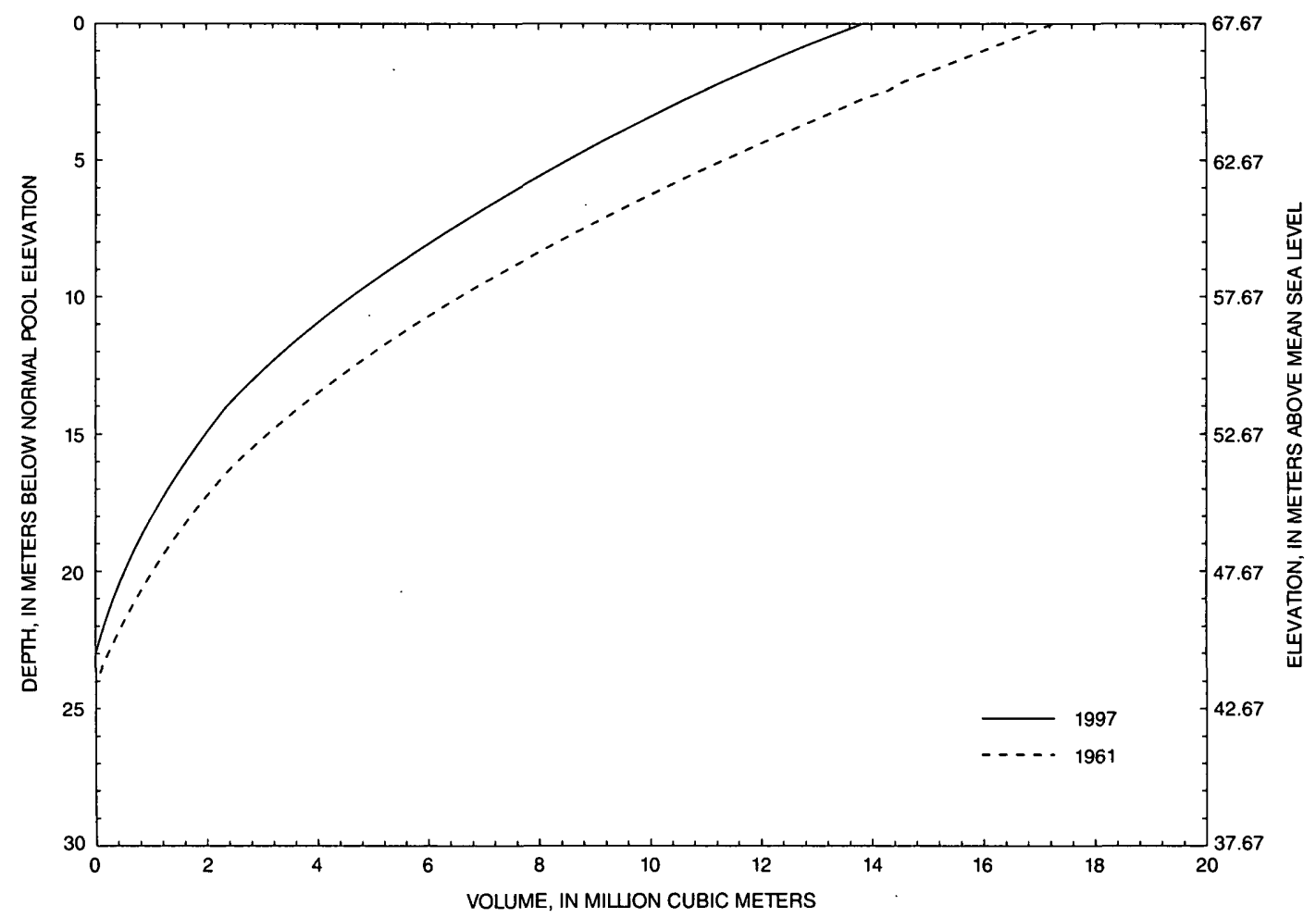

Figure 7. The relation between pool elevation and volume derived from triangulated irregular network surface model (1997) and from photogrammetric methods (1961) for Lago Patillas, Puerto Rico.

\section{REFERENCES}

Brune, G.M., 1953, Trap efficiency of reservoirs: Transactions of the American Geophysical Union, v. 34, no. 3, p. 407-418.

Calvesbert, R.J., 1970, Climate of Puerto Rico and the U.S. Virgin Islands: U.S. Department of Commerce, Environmental Science Services Administration, $29 \mathrm{p}$.

Díaz, P.L., Aquino, Zaida, Figueroa-Alamo, Carlos, Vachier, R.J., and Sánchez, A.V., 1996: U.S. Geological Survey Water-Data Report PR-96-1, p. 350-353.

Environmental Systems Research Institute, Inc., 1992, Surface modeling with TIN, Surface analysis and display: Environmental Systems Research Institute, Inc., Redlands, California, p. 4-1, 6-1.

Giusti, E.V., and López, M.A., 1967, Climate and streamflow of Puerto Rico: Caribbean Journal of Science, v. 7 no. 3-4, September-December 1967 , p. 87-93.
Heinemann, H.G., and Dvorak, V.I., 1963, Improved volumetric survey and computation procedures for small reservoirs: U.S. Department of Agriculture Miscellaneous Publication 970, Symposium 7--Sedimentation in reservoirs, p. 845-856.

McManus, J., and Duck, R.W., eds., 1993, Geomorphology and sedimentology of lakes and reservoirs: Chapter 6, Reservoir sedimentation rates in the Southern Pennine Region, UK: Chichester, John Wiley \& Sons, p. 73-92.

Puerto Rico Electric and Power Authority, 1979, Patillas Dam, Patillas, Puerto Rico: Phase I Inspection Report: National Dam Safety Program, 1979.

U.S. Bureau of Reclamation, 1976, Designers' operation criteria for Patillas dam spillway replacement, Patillas, Puerto Rico: U.S. Bureau of Reclamation report to the Puerto Rico Water Resources Authority, 25 p., 24 plates. 
District Chief

Caribbean District

U.S. Geological Survey

Water Resources Division

GSA Center, Suite 400-15

651 Federal Drive

Guaynabo, Puerto Rico 00965-5703

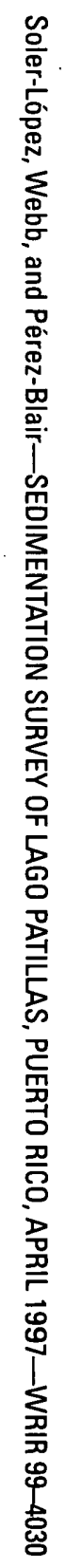

